\title{
VIRTUAL ELIMINATION OF DIOXIN: \\ EFFORTS OF THE UNITED STATES AND CANADA TO \\ ELIMINATE DIOXIN POLLUTION AS REQUIRED BY THE GREAT LAKES WATER QUALITY AGREEMENT
}

\section{INTRODUCTION}

The Great Lakes watershed is a clean, safe environment where life forms exist in harmony. People take pride in the Great Lakes. We share and live an ethic which recognizes that environmental integrity provides the foundation for a healthy economy. We are secure in the knowledge that fish and wildlife are healthy to eat and the water can be enjoyed by all. We understand our responsibility for ensuring a self-sustaining Great Lakes ecosystem. This is the example we set for the rest of the world and the legacy we leave our children. ${ }^{1}$

Although we wish the above statement were true, the reality is that the Great Lakes are not a clean, safe environment; many of the fish and wildlife are not safe to eat; and the legacy we leave our children could be a life of physical and mental problems associated with toxic contamination. In 1972, Canada and the United States recognized the importance of the Great Lakes and the pollution that was seriously deteriorating them by signing the Great Lakes Water Quality Agreement ("GLWQA" or "Agreement"). The original Agreement focused on nutrients and eutrophication in the Lakes. Today, however, the countries' main focus is on the problem of persistent, bioaccumulative toxic chemicals.

One persistent, bioaccumulative toxic contaminant that has spurred much controversy is dioxin. Dioxin is a by-product of chemical and industrial manufacturing processes and combustion. Dioxin has been called one of the most powerful poisons ever studied. One source of dioxin that has been the focus of many statutes and regulations is the pulp and paper industry.

In 1994, the Environmental Protection Agency ("EPA") released a Draft Reassessment of dioxin which analyzed the effects on humans of low level exposure to dioxin. The Reassessment and other studies contend that at low level doses, dioxin causes many adverse health effects such as infertility, immune system impairment, disruption of sexual development, cancer, and behavioral disorders. Other groups assert that the EPA does not

1. INTERnational JoInt Commission, Sixth Biennial REPORT on Great LaKes WATER Quality 46 (1992) [hereinafter SIXTH BIENNIAL REPORT]. This is the vision statement proposed by the Great Lakes Water Quality Board in 1991. Id. 
yet have enough evidence of the harms caused by low level exposure to dioxin to warrant costly regulation of dioxin discharges. This disagreement emphasizes the fundamental differences between the weight of the evidence approach, as recommended by the International Joint Commission ("IJC"), and risk assessment approaches, as recommended by the industry groups.

In compliance with the GLWQA, the United States and Canada have each promulgated several statutes and regulations to govern discharges of dioxin by the pulp and paper industry. Some of the U.S. efforts include the Great Lakes Water Quality Initiative, the Pollution Prevention Act, and the proposed Cluster Rule. Canadian efforts include the Canada-Ontario Agreement Respecting the Great Lakes Ecosystem and the Federal Toxic Substances Management Policy. The combined efforts of the countries along with voluntary efforts by the industry have resulted in a greater than ninety percent reduction in dioxin discharges by the pulp and paper mills.

Part I of this note details the history between the United States and Canada that led to the GLWQA and discusses the provisions and purposes of this Agreement. Part II addresses the questions of what dioxin is and why the public should be concerned with it. The efforts of the United States and Canada to comply with the Agreement and the advantages and disadvantages of the efforts of each country are considered in Part III and Part IV, respectively. Lastly, Part V contains conclusions and recommendations.

\section{TREATIES AND AGREEMENTS CONCERNING THE GREAT LAKES}

\section{A. The Boundary Waters Treaty of 1909}

In order to fully understand how and why the Great Lakes Water Quality Agreement was established, the history of relations between the United States and Canada concerning the Great Lakes should be analyzed. This history begins with the Boundary Waters Treaty of 1909 . The main concerns behind the formation of the Treaty were navigation, water diversion, and irrigation rights along border waters of the United States and Canada. Public pressure over concerns with the diversion of water for hydroelectric power generation and its effects on water levels and navigation spurred the two countries into action and resulted in the signing of the Boundary Waters Treaty. ${ }^{2}$

2. Daniel K. DeWitt, Great Words Needed for the Great Lakes: Reasons to Rewrite the Boundary Waters Treaty of 1909, 69 IND. L.J. 299, 305 (1993). The hydroelectric power controversies focused on proposed plans to divert water from the St. Mary's River at Sault Ste. Marie and at Niagara Falls. Id. 


\section{Purpose and General Provisions of the Boundary Waters Treaty}

The purpose of the Boundary Waters Treaty, as stated in the preamble, was

to prevent disputes regarding the use of boundary waters and to settle all questions which are now pending between the United States and the Dominion of Canada involving the rights, obligations, or interests of either in relation to the other or to the inhabitants of the other, along their common frontier, and to make provision for the adjustment and settlement of all such questions as may hereafter arise. ${ }^{3}$

The Treaty applies to all "waters straddling the border," such as the Great Lakes. ${ }^{4}$ Articles I through VI discuss the countries' respective rights in the areas of navigation, diversion, and irrigation. The principles of free navigation ${ }^{5}$ in the Great Lakes and protection against interference with the "natural level or flow of boundary waters" 6 are the foundation of these Articles.

\section{Pollution Provision}

Article IV contains the only mention of pollution in the Treaty. The Article states that it is "agreed that the waters herein defined as boundary waters and waters flowing across the boundary shall not be polluted on either side to the injury of health or property on the other." Although the early 1900 's and the Industrial Revolution marked the beginning of the Great Lakes' pollution, at the time of the treaty's signing, it was not considered an "international" problem. ${ }^{8}$ The pollution problems at that time were mainly municipal sewage contamination and were considered "local" problems."

3. Boundary Waters Treaty, Jan. 11, 1909, U.S.-Gr. Brit., 36 Stat. 2448, 2448 [hereinafter BWT].

4. DeWitt, supra note 2, at 306.

5. BWT, supra note 3, at 2449.

6. Id.

7. Id. at 2450.

8. DeWitt, supra note 2 , at 304-05.

9. Id. The discharge of sewage into the Great Lakes resulted in cities polluting their own water supplies when the same water was then used by the citizens for drinking. The contamination caused outbreaks of typhoid which killed 25,000 people in the United States by 1912. Id. at 304. 


\section{The International Joint Commission}

The lasting legacy of the Boundary Waters Treaty has been the formation of the International Joint Commission ("IJC"). Articles VII through XII of the Treaty created the IJC, which consists of six commissioners. ${ }^{10}$ Three commissioners are appointed by each government and have a goal of acting "as a single body seeking common solutions rather than as separate national delegates representing the positions of their Governments." 11

The duties and responsibilities of the IJC can be divided into three separate categories: “(1) quasi-judicial determinations; (2) investigative and advisory assignments; and (3) arbitrations." 12 The quasi-judicial function of the IJC includes "deciding whether certain kinds of works or activities can be built or undertaken in rivers or lakes that flow along or across the international boundary." ${ }^{13}$ The investigative and advisory duties typically involve examining problems submitted to the IJC and setting out conclusions and recommendations in reports. ${ }^{14}$ However, the IJC has no authority to initiate or enforce activities. ${ }^{15}$ The arbitration function is used only if both countries consent to the IJC resolving the issue in binding arbitration. ${ }^{16}$ However, the IJC has never been authorized to use this function. ${ }^{17}$

Until the 1960's, the IJC was called upon to investigate pollution only a few times. However, in 1964, concern over eutrophication, oil spills, mercury, and polychlorinated biphenyls ("PCB's") in Lake Erie, Lake Ontario, and the St. Lawrence River resulted in the IJC performing a massive analysis of the pollution and the Lakes. ${ }^{18}$ As a result of the research, the IJC declared that Lake Erie was "dead." 19 The IJC made many recommendations to the United States and Canada, such as emergency remedial action to control and reduce the pollution and new authority and

10. BWT, supra note 3, at 2451.

11. INTERNATIONAL JOINT COMMISSION, THE INTERNATIONAL JOINT COMMISSION AND THE BOUNDARY WATERS TREATY 3-4 (1990) [hereinafter INTERNATIONAL JOINT COMMISSION AND TREATY].

12. James G. Chandler \& Michael J. Vechsler, The Great Lakes-St. Lawrence River Basin from an IJC Perspective, 18 CAN.-U.S. L.J. 261, 263 (1992).

13. Id.

14. DeWitt, supra note 2 , at 308.

15. Id.

16. Id. See also BWT, supra note 3, at 2453.

17. Chandler \& Vechsler, supra note 12, at 263.

18. Id. at 273.

19. Sean P. Gallagher, Note, Great Lakes Water Quality Initiative: National Standards Governing a Binational Resource. A Call for International Rulemaking, 2 IND. J. GLOBAL LEGAL STUD. 465, 467 (1995). 
powers for the IJC. ${ }^{20}$ The IJC's recommendations led to implementation of the 1972 Great Lakes Water Quality Agreement.

\section{B. The Great Lakes Water Quality Agreement}

The original Great Lakes Water Quality Agreement was signed in 1972. However, changing concerns resulted in the Agreement being replaced in 1978 and amended in 1987.

\section{The Great Lakes Water Quality Agreement of 1972}

The 1972 GLWQA maintained the rights and obligations of Canada and the United States as set out under the Boundary Waters Treaty. ${ }^{21}$ However, the countries were "[s]eriously concerned about the grave deterioration of water quality on each side of the boundary to an extent that [was] causing injury to health and property on the other side."22 The Agreement's general objectives were to keep the waters free from: (1) substances that adversely affect aquatic life or waterfowl; (2) debris, oil, scum, or materials that produce foul color, odor, or taste; (3) toxins; and (4) nutrients. ${ }^{23}$ The main focuses of the Agreement were phosphorus and sewage in the lakes' waters. ${ }^{24}$

The IJC was also given new powers in the Agreement, which included "analyzing information relating to water quality; evaluating the effectiveness of programs; giving recommendations concerning water quality objectives, legislation, and other regulatory standards; and assisting in the coordination of joint activities." 25 The Great Lakes Water Quality Board and the Research Advisory Board were established to assist the IJC in performing these new functions. ${ }^{26}$ Lastly, the IJC was also required to submit an annual report to the governments detailing progress on the goals of the Agreement. ${ }^{27}$

20. DeWitt, supra note 2, at 311.

21. Great Lakes Water Quality Agreement of 1972, Apr. 15, 1972, 23 U.S.T. 301, 302 [hereinafter 1972 GLWQA].

22. Id.

23. Id. at 304.

24. Id. at 305-06. Eutrophication results when nutrients, such as phosphorus, cause the growth of algae, weeds, and slimes. These growths exhaust the oxygen supply in the water and cause fish and other aquatic life to die from lack of oxygen. Phosphorus enters the water supplies through detergents and sewage. Chandler \& Vechsler, supra note 12, at 274.

25. Gallagher, supra note 19 , at 468-69.

26. 1972 GLWQA, supra note 21 , at 309-10.

27. Id. at 309. 


\section{The Great Lakes Water Quality Agreement of 1978}

The 1972 GLWQA was replaced in 1978 by a new and more comprehensive agreement. The purpose of the modified Agreement was "to restore and maintain the chemical, physical, and biological integrity of the waters of the Great Lakes Basin Ecosystem."28 This "ecosystem approach" means that the integrity of the water, land, air, wildlife, and people in the Great Lakes Basin must all be considered. ${ }^{29}$ This approach also mandates a more "holistic" approach than the current "pollutant-by-pollutant approach to improvement of water quality." 30

Another major change from the 1972 GLWQA to the 1978 GLWQA was the shift from a focus on phosphorus to a focus on toxic chemicals. The IJC used five factors to decide which pollutants were a priority for the countries. These factors include: “(1) presence and ambient concentration in the Great Lakes environment; (2) degree of toxicity; (3) persistence in the environment; (4) bioavailability; and (5) potential to bioconcentrate and bioaccumulate." The countries stated that it was their policy that "[t]he discharge of toxic substances in toxic amounts be prohibited and the discharge of any or all persistent toxic substances be virtually eliminated. ${ }^{32}$

\section{1987 Protocol Amending the 1978 Great Lakes Water Quality Agreement}

The 1987 amendments "strengthen the programs, practices and technology described in the 1978 Agreement and . . increase accountability

28. Great Lakes Water Quality Agreement of 1978, Nov. 22, 1978, 30 U.S.T. 1383, 1387 [hereinafter 1978 GLWQA].

29. The Great Lakes Ecosystem (online version), GREAT LAKES INFORMATION NETWORK, rev. Aug. 31, 1995, at 1, available in Internet, http://www.greatlakes.net:2200/ecosystem/ecosys.html.

30. Joseph F. Koonce, Aquatic Community Health of the Great Lakes (online version), SOLEC Working Paper presented at State of the Lakes Ecosystem Conference, EPA 905-D94-001a, CONSORTIUM FOR INTERNATIONAL EARTH SCIENCE INFORMATION NETWORK (CIESIN), Oct. 1994, at 5, available in Internet, http://epawww.ciesin.org/glreis/nonpo/ ndata/solec/aquatic/aquatic.html.

31. Jack Manno et al., Effects of the Great Lakes Basin Environmental Contaminants on Human Health (online version), SOLEC Working Paper presented at State of the Great Lakes Ecosystem Conference, EPA 905-R-95-013, CONSORTIUM FOR INTERNATIONAL EARTH SCIENCE INFORMATION NETWORK (CIESIN), Aug. 1995, at 8, available in Internet, http://epawww.ciesin.org/glreis/nonpo/ndata/solec/health/health.html.

32. 1978 GLWQA, supra note 28, at 1387 (emphasis added). The Agreement defines a persistent toxic substance as a toxic substance with "a half-life in water of greater than eight weeks." Id. at 1445. A half-life is the "time required for the concentration of a substance to diminish to one-half of its original value in a lake or water body." Id. 
for their implementation." ${ }^{33}$ Other major advancements created in the 1987 amendments were the use of Remedial Action Plans ("RAP's") and Lakewide Management Plans ("LaMP's"). RAP's “identify specific problems in severely degraded Great Lakes Areas of Concern (AOC) and describe methods for correcting them." 34 The 1987 Amendments "directed the two federal governments to cooperate with state and provincial governments to develop and implement [RAP's] for each [AOC]" by using the ecosystem approach. ${ }^{35}$ LaMP's are "designed to reduce inputs of critical pollutants into the Great Lakes and to restore and maintain integrity of the Great Lakes." ${ }^{36}$ The LaMP's also "coordinate existing regulations and programs, identify gaps in these programs, and recommend solutions to problems threatening the Great Lakes ecosystem." 37

\section{Is the Great Lakes Water Quality Agreement Binding on the United States and Canada?}

There has been much debate over whether the GLWQA is legally binding on Canada and the United States. Some contend that when Congress promulgated the Critical Programs Act ${ }^{38}$ in 1990 their intent was to codify the requirements of the GLWQA. ${ }^{39}$ It has also been explained that under international law, agreements are binding as treaties. ${ }^{40}$ However, EPA officials conclude that the language of the GLWQA sets objectives and goals, not legally binding, precise standards. ${ }^{41}$ They also conclude that the Critical Programs Act directs the EPA to "adopt [a] guidance that 'conforms' with

33. INTERNATIONAL JOINT COMMISSION AND TREATY, supra note 11, at 4.

34. Remedial Action Plans for Great Lakes Areas of Concern (online version), GREAT LAKES INFORMATION NETWORK, rev. Oct. 25, 1995, at 1, available in Internet, http://www. great-lakes.net:2200/envt/water/watqual $/ \mathrm{manag} / \mathrm{rap} / \mathrm{rap} . \mathrm{html}$.

35. Id. As of October 1995, 43 AOC's have been named. Twenty-six of these are in the United States, while 17 are in Canada. Five are joint AOC's between the United States and Canada because they are connecting river systems. Id.

36. Guide to Lakewide Management Plans (LaMPs) (online version), CONSORTIUM FOR INTERNATIONAL EARTH SCIENCE INFORMATION NETWORK (CIESIN), Dec. 5, 1993, at 1, available in Internet, http://epaserver.ciesin.org/glreis/glnpo/prog/lamps/lamps-home.html.

37. Id.

38. See infra part III(A)(2) for a discussion of the Critical Programs Act.

39. Gallagher, supra note 19 , at 478 .

40. Id. at 478 n.110 (quoting United States/Canada Great Lakes Water Quality Agreement: Hearing Before the Subcomm. on Investigations and Oversight of the House Comm. on Public Works and Transportation, 99th Cong., 2d Sess. 5 (1986) (statement of Hon. James L. Oberstar, Chairman Subcomm. on Investigations and Oversight)).

41. What the U.S. EPA Says About the Great Lakes Water Quality Initiative and Complying (Partly) with the Great Lakes Water Quality Agreement (online version), GREAT LaKes Natural Resource Center, NAtional Wildlife Federation, June 1, 1995, at 1, available in Internet, http://www.great-lakes.net:2200/0/partners/NWF/gli/sid/sid-wqa.html. 
the objectives of the GLWQA," not a guidance that is the same as the GLWQA objectives. ${ }^{42}$ Therefore, the binding ability of the GLWQA has not yet been resolved.

\section{DioxIN - Persistent ToXIC SubSTANCES}

\section{A. What is Dioxin and What are Its Sources?}

In 1986, researchers reported that dioxin was one of the most powerful poisons ever studied. ${ }^{43}$ Dioxin is actually a family of seventy-five chemicals in which 2,3,7,8-tetrachlorodibenzo-p-dioxin ("TCDD") is the most potent. ${ }^{44}$ Several other chemicals, such as PCB's, are more widely known by the general public and are "dioxinlike," which means that they have similar effects as dioxin at different concentrations. ${ }^{45}$

Unlike PCB's, which were used as electrical insulators, dioxins are not intentionally created by humans. ${ }^{46}$ Dioxins are by-products of combustion and chemical and industrial manufacturing processes which use chlorine. ${ }^{47}$ Approximately ninety-five percent of dioxin is produced by incineration,

42. Id. at 1-2.

43. Peter Montague, Dioxin Inquisition (online version), RACHEL's ENVIRONMENT \& HEALTH WEEKLY \#457, Aug. 31, 1995, at 1, available in Internet, http://www. bluemarble.net/ $\sim$ mitch/bull/toxics/dioxininquisit.html. This finding by U.S. EPA researchers resulted in strict limits being proposed on dioxin releases. However, before the limits could be enforced, industry leaders challenged the EPA's findings and forced the agency to perform a major reassessment of dioxin. Id.

44. Putting the Lid on Dioxins: Protecting Human Health and Environment (online version), PHYSICIANS FOR SOCIAL RESPONSIBILITY \& ENVIRONMENTAL DEFENSE FUND, Summer 1994, at 3, available in Internet, http://gopher.great-lakes.net:2200/0/waterairland /toxics/dioxin/dioxin.txt [hereinafter Putting the Lid].

45. Id. at 3-4.

46. Id. at 9. See also INTERNATIONAL JOINT COMMISSION GREAT LAKES WATER QUALITY BOARD, RE-EVALUATION OF DIOXIN 2 (1993)[hereinafter RE-EVALUATION OF DIOXIN].

47. D. DeVault et al., Toxic Contaminants in the Great Lakes (online version), SOLEC Working Paper presented at State of the Lakes Ecosystem Conference, EPA 905-D-94-001e, CONSORTIUM FOR INTERNATIONAL EARTH SCIENCE INFORMATION NETWORK (CIESIN), Oct. 1994, at 19-20, available in Internet, http://epaserver.ciesin.org/glreis/nonpo/ndata/ solec/toxic/toxic.html.

Sources of pollution are also often described as point and nonpoint sources. Examples of point sources include smoke stacks, waste outlets, and discharge pipes. Nonpoint sources include runoff and deposition from the atmosphere. Pollution in the Great Lakes Region (online version), GREAT LAKES INFORMATION NETWORK, Oct. 6, 1995, at 1 , available in Internet, http://www.great-lakes.net:2200/ecosystem/pollution/pollut.html. In relation to dioxin pollution, pulp and paper mills would be point sources because they discharge contaminants directly into water. 
particularly incineration of medical and municipal waste, when chlorinated hydrocarbons, such as plastics, are burned. ${ }^{48}$

Another known source of dioxin is the bleaching of paper and pulp products with chlorine. ${ }^{49}$ This note will focus on dioxin released by this source. Currently, seventy-two pulp and paper mills discharge into the Great Lakes basin. ${ }^{50}$ Mills using chlorine in their processes produce dioxin as a by-product. The adverse impact of pulp and paper mills on water quality is evident in fifteen of forty-three Areas of Concern designated in the Great Lakes area. ${ }^{51}$

Lastly, there are also natural sources of dioxin, such as forest fires and volcanoes. ${ }^{52}$ However, natural sources are not likely to be a major source of dioxin since analyses of soils show that dioxin did not appear in significant quantities until the 1920's when industries began heavy use of chlorinated organics. ${ }^{53}$ Although many sources of dioxin are now known to scientists, much of the new input into the environment is still unknown. ${ }^{54}$

\section{B. Routes of Exposure to Dioxin}

There are several routes other than industrial accidents by which humans and wildlife are exposed to dioxin. In the Great Lakes area, the leading route of exposure is through food consumption, especially fish. Dioxin enters the food chain through bioaccumulation, which is the process by which "a substance is assimilated into an organism through eating another organism (plant or animal). Depending on the substance, it may be passed through the body fairly quickly, or it may accumulate in certain organs or tissues, thus enabling the chemical to concentrate in body tissues." As one organism eats another, this process continues and dioxin becomes "increasingly concentrated or biomagnified." 56

48. Victor Wigotsky, The Chlorine Issue; Environmental Effects of Chlorine-Containing Compounds, Plastics EngINEERING, Feb. 1995, at 19. See also US EPA Dioxin Reassessment Report Intensifies International Debate, BUSINESS \& THE ENVIRONMENT, Oct. 1994.

49. RE-EVAluation of Dioxin, supra note 46 , at 2.

50. INTERNATIONAL JOINT COMMISSION, 1993-95 PRIORITIES AND PROGRESS UNDER THE GREAT LAKES WATER QUALITY AGREEMENT 35 (1995) [hereinafter 1993-95 PRIORITIES]. Eighteen of the mills are in Ontario; twenty are in Michigan; twenty are in Wisconsin; twelve are in New York; and two are in Ohio. Id.

51. Id.

52. Wigotsky, supra note 48 , at 18.

53. Putting the Lid, supra note 44, at 9. See also RE-EVALUATION OF DIOXIN, supra note 46 , at 2 .

54. RE-EVAluation OF DioXiN, supra note 46 , at 2.

55. Manno, supra note 31 , at 9.

56. Id. 
Dioxin bioaccumulates in the fatty tissues of fish and animals. As dioxin is deposited in the sediments of the lakes and rivers, scavenger fish eat the deposited dioxin, and the toxin accumulates in their fatty tissue. Predator fish then consume the scavenger fish, and the predator fish are later eaten by birds, such as eagles. This leads to increasing concentrations of the dioxin as it goes up the food chain. Thus, by a human eating a single serving of moderately contaminated fish, he or she receives the equivalent quantity of toxic chemicals as drinking several million gallons of water in which the fish lived. ${ }^{57}$

Consumption of drinking water is also suspected to be a route of exposure to dioxin. The EPA has estimated that everyday 12.7 million people drink water from the Great Lakes that is contaminated with some toxic pollutant. ${ }^{58}$ Another route of exposure is inhalation of the polluted air. Lastly, skin contact with contaminated water is also now suspected to be an exposure route. ${ }^{59}$ However, this route is the least significant path of exposure. ${ }^{60}$

\section{Effects of Dioxin on Humans and Wildlife}

In September 1994, the EPA released its Draft Reassessment of dioxin. The eight-volume, 2000 page report is a comprehensive review of the health risks posed by dioxin. ${ }^{61}$ The report and many other scientific studies have discussed the effects of dioxin on wildlife, the aquatic community, and humans. At very high doses, dioxin causes death in all species that have been studied. ${ }^{62}$ However, the EPA report also discusses the effects of dioxin at low-level exposures. ${ }^{63}$

\section{Effects on Wildlife and the Aquatic Community}

While data on the health effects of dioxin on humans is limited, data on the health effects on wildlife is considerable. ${ }^{64}$ Dioxin and other

57. Hormone Copycats: Effects (online version), GREAT LAKES NATURAL RESOURCE CENTER, NATIONAL Wildlife FEDERATION, Apr. 4, 1994, at 2, available in Internet, http://www.great-lakes.net:2200/0/partners/NWF/toxics/hcc2-hcc.html.

58. Manno, supra note 31 , at 11.

59. Id.

60. This route of exposure is likely to pose a large risk only to a marathon swimmer. ld.

61. Putting the Lid, supra note 44 , at 1.

62. RE-EVALUATION OF DioXIN, supra note 46, at 3.

63. For a summary of the Draft Reassessment, see William H. Farland, EPA's Reassessment of Dioxin, CONGREsSIONAL TESTIMONY BY FEDERAL DOCUMENT ClEARING HOUSE, Dec. 13, 1995, available in Westlaw, 1995 WL 13415464.

64. SIXTH BIENNIAL REPORT, supra note 1, at 20. 
persistent toxic chemicals have had a significant effect on wildlife in the Great Lakes area. In 1992, the IJC reported that dioxin and other similar chemicals caused thyroid dysfunction, decreased fertility, decreased hatching success, increased gross birth defects, and many other adverse health effects in wildlife. ${ }^{65}$

Significant evidence of dioxin's effects on wildlife have been shown in many studies. Several bird species were almost extinct in the Great Lakes Basin in the 1950's and 1960's due to decreased hatching success caused by persistent toxic chemicals. ${ }^{66}$ In the 1980 's, dioxin released by pulp and paper mills in Vancouver contaminated fish near Vancouver Island. ${ }^{67}$ In 1987, a group of great blue heron, which ate the contaminated fish, produced no offspring. ${ }^{68}$ None of the 179 eggs produced that year hatched. ${ }^{69}$ Although the next year some of the eggs hatched, none of the new chicks survived more than a few weeks. ${ }^{70}$ Studies of the egg shells showed high concentrations of dioxin. ${ }^{71}$ Similar effects have been seen in the Great Lakes in the bald eagle and Caspian terns. ${ }^{72}$ Other wildlife in the Great Lakes basin, such as otter and mink, has also shown reproductive difficulties and other problems associated with toxic chemicals. ${ }^{73}$

Many of the Great Lakes fish have also shown effects of dioxin and similar chemicals. ${ }^{74}$ Some of the effects include serious reproductive problems, goiters, lack of secondary sexual characteristics, and severe deformities. ${ }^{75}$ Dioxin levels have decreased in the Great Lakes over the past few years. However, fish do not get rid of dioxin once it is accumulated in their fatty tissue, and a fish that consumed dioxin-contaminated foods in the

65. Id. at 18.

66. Dioxin Risks High Enough to Take Action, EPA Scientists Say, PESTICIDE \& ToxIC Chemical News, Oct. 26, 1994.

67. Glenn Bohn, Defeating the Dioxins: Just a few years after pulp and paper mills started to clean up their act, a major poison in the Fraser River ecosystem is in dramatic decline, THE VANCOUVER Sun, May 8, 1993, at B4.

68. Id.

69. Id.

70. Id.

71. Id.

72. SIXTH BIENNIAL REPORT, supra note 1, at 22-23.

73. Hormone Copycats: Effects on Wildlife (online version), GREAT LAKEs NATURAL ResourCe Center, NATIONAL Wildlife Federation, Apr. 4, 1994, at 13, available in Internet, http://www.great-lakes.net:2200/0/partners/NWF/toxics/hcc3-wil.html.

74. Id. at 4. Fish in the Great Lakes affected include lake trout, lake herring, lake whitefish, and deepwater sculpin, which died out in the Great Lakes in the 1960's. Great Lakes salmon have also shown severe effects. Id.

75. Id. Examples of deformities include twisted spines, double heads, clubbed tails, and missing eyes. Id. 
late 1980 's may still be contaminated even though fewer dioxins are being dumped into the Great Lakes. ${ }^{76}$

\section{Effects on Humans}

The effects of dioxin on humans are much more difficult to determine than the effects on wildlife. Other than studies of people exposed to dioxin during industrial accidents, the effects must be determined by experiments on laboratory animals which are similar to humans. Some groups have criticized this by saying that results from animal experiments are not representative of the effects on humans.

However, in 1992 the IJC recommended that the United States and Canada adopt a "weight of the evidence" approach to persistent toxic chemicals. ${ }^{77}$ This approach looks at the cumulative weight of studies to determine if a real or a strong probability of a linkage between certain substances and injury can be made. ${ }^{78}$ The conclusion is made on "the basis of common sense, logic and experience as well as formal science."79 The basis of the weight of the evidence approach is that "waiting for absolute assurance capable of convincing even the most sceptical [sic] scientist, may result in irreparable and irreversible damage to the ecosystem and human health." 80 This is the approach used by the EPA and many other scientists in forming conclusions on the effects of dioxin on humans.

\section{a. Chloracne}

Chloracne is the "hallmark" of dioxin toxicity. ${ }^{81}$ This skin disorder, caused by exposure to dioxin, is a very severe, persistent form of cystic acne that affects people over their entire body. ${ }^{82}$ Some people exposed to dioxin over forty years ago in industrial accidents still have active chloracne. ${ }^{83}$

76. Bohn, supra note 67 , at B4.

77. SiXTH BIENNIAL REPORT, supra note 1, at 22. See also INTERNATIONAL JOINT

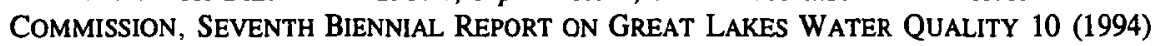
[hereinafter SEVENTH BIENNIAL REPORT].

78. SEVENTH BIENNIAL REPORT, supra note 77, at 10.

79. Id.

80. 1993-95 PRIORTTIES, supra note 50, at 5.

81. RE-EVALUATION OF DioXIN, supra note 46 , at 3.

82. Id.

83. Id. 


\section{b. Immune System}

In its Dioxin Reassessment, the EPA concluded that even at low level doses, dioxin impairs normal immune function in laboratory animals and is likely to do the same in humans. The effects could include suppression of the immune system which could lead to increased susceptibility to bacterial, viral, and parasitic diseases along with cancers. These effects have been observed in children exposed in utero to dioxin and other similar toxins. ${ }^{84}$

\section{c. Hormone Mimicking and Sexual Development}

Dioxin has also been shown to have disrupting effects on the reproductive systems and the endocrine system, which produces hormones responsible for regulating metabolism, responding to stress, and coordinating sexual development and reproduction processes ${ }^{85}$ Hormone mimicking is the process by which toxic chemicals mimic the "critical functions of human hormones." ${ }^{86}$ When this occurs, "[t]he body mistakes [the toxins] for natural hormones and reacts to them in ways that cause deep and permanent trouble, especially when exposure occurs during the critical period[s] of development, before [birth], and immediately after birth." 87

Scientists believe that hormone mimicking can have severe effects on human sexual development. For example, animal studies have shown that young male rats exposed to small amounts of dioxin in utero are often born with several defects, such as: (1) smaller sexual organs; (2) slower sexual maturation; (3) "greater willingness to assume a receptive-female posture when approached by a sexually stimulated male, ${ }^{88}$ and (4) reduced sperm

84. Putting the Lid, supra note 44 , at 7 . For example, in 1979 , rice oil contaminated with PCB's and polychlorinated dibenzofurans was eaten in the Yu-Cheng province of Taiwan. Children born to mothers who ate the rice oil have been involved in an extensive study. These $\mathrm{Yu}$-Cheng children have had a higher rate of respiratory and ear infections and a decreased rate of successful vaccinations. Id. at 7,12 . These effects have also been observed in the Inuit children from Quebec who were exposed in utero to toxic chemicals when their mothers ate contaminated seal and whale meat. Hormone Copycats: Effects on Humans (online version), Great Lakes Natural Resource Center, National Wildlife Federation, Apr. 4, 1994, at 4-5, available in Internet, http:/www.great-lakes.net:2200/0/partners/NWF/ toxics/hcc4-hum.html.

85. Hormone Copycats: Effects, supra note 57, at 2.

86. GORDON K. DURNIL, THE MAKING OF A CONSERVATIVE ENVIRONMENTALIST 79 (1995) (quoting Hormone Copycats: New Pollution Threat to the Great Lakes Environment, NATIONAL WiLdLIFE FEDERATION, Aug. 16, 1993).

87. Id.

88. Montague, supra note 43, at 2. Similar effects have been noted in women exposed in utero to the drug DES during their mothers' pregnancies. Studies have shown that exposure to DES "increases the likelihood of major depressive disorders, as well as bisexual activity and interest in adult women." For example, a study of sisters indicate that $42 \%$ of the sisters 
production. ${ }^{89}$ This study is partially confirmed by a study of the Yu-Cheng children who were exposed to a dioxin-like chemical in utero. ${ }^{90}$ The children are beginning to show defects in their sexual development. ${ }^{91}$ It should also be noted that "[t]he average man today produces only half as much sperm as his grandfather did." 92 Scientists are beginning to believe that this may be partially the result of exposure to toxic chemicals, such as dioxin. ${ }^{93}$

Animal studies have also shown that dioxin may also be linked to endometriosis, a painful women's disease in which "bits of uterine lining . . . migrate generally to other pelvic organs and can cause infertility, internal bleeding, and other serious problems." 94 Endometriosis has been increasing in frequency in U.S. women. ${ }^{95}$

\section{d. Cancer}

The average man is "far more likely [than his grandfather] to contract certain cancers, including prostate and testicular cancer." 96 Today, the average woman is "twice as likely to contract breast cancer as her grandmother." Al Although there is no clear evidence, many scientists believe that these statistics are associated with the increase in toxic chemicals in the environment. In laboratory studies of other mammals, dioxin causes

who were exposed to DES in utero have a bisexual orientation, while only $8 \%$ of the sisters not exposed to DES have a bisexual orientation. Hormone Copycats: Effects, supra note 57, at 4.

89. Montague, supra note 43, at 2.

90. See supra note 84.

91. Hormone Copycats: Effects on Humans, supra note 84, at 2. See also Putting the Lid, supra note 44 , at 6.

92. Hormone Copycats: Summany (online version), GREAT LAKES NATURAL RESOURCE CENTER, NATIONAL WILDLIFE FEDERATION, Apr. 4, 1994, at 3, available in Internet, http://www.great-lakes.net:2200/0/partners/NWF/toxics/hcc0-sum.html. The Danish Environmental Protection Agency recently completed a study which showed a dramatic decline in sperm counts and increased testicular cancer, undescended testis, and genital tract disorders. INTERNATIONAL JOINT COMMISSION, EIGHTH BIENNIAL REPORT UNDER THE GREAT LAKES WATER QUALITY AGREEMENT OF 1978 10-11 (1996), available in Internet, http://www.greatlakes.net:2200/partners/LJC/html/8bien/repeng.html [hereinafter EIGHTH BIENNLAL REPORT].

93. See RE-EVAlUATION QF Dioxin, supra note 46, at 14. See also Mark Nichols, The Sperm Scare: Pollution and Chemicals May Be Threatening Human Fertility, MACLEAN's, Apr. 1, 1996, available in Westlaw, 1996 WL 8016152.

94. Hormone Copycats: Effects on Humans, supra note 84, at 4 . See also REEVALUATION OF DIOXIN, supra note 46, at 11.

95. Peter Montague, Dioxin and Health (online version), RACHEL's ENVIRONMENT \& HEALTH WEEKLY \#463, Oct. 12, 1995, at 3, available in Internet, http://www.bluemarble. net/ mitch/bull/toxics/diox-health.html.

96. Hormone Copycats: Summary, supra note 92, at 3.

97. Id. 
multiple tumors and cancer. ${ }^{98}$ Cancer studies in Seveso, Italy, where an explosion at a chemical plant released large amounts of dioxin in 1976, have shown very significant increases in tumors. ${ }^{99}$ Also, Vietnam veterans exposed to dioxin-contaminated Agent Orange have reported a higher incidence of some cancers. ${ }^{100}$

\section{e. Behavioral Effects and Learning Disorders}

Dioxin and other similar chemicals are suspected of causing behavioral and learning disorders when children are exposed in utero. Yu-Cheng children who were exposed to toxic chemicals similar to dioxin in utero in $1978^{101}$ have shown higher activity levels, lower adaptability, negative moods, and more intense reactions. ${ }^{102}$ The children have more health, habit, and behavior problems and have an average IQ four to five points lower than unexposed children. ${ }^{103} \mathrm{~A}$ recent study has also shown that toxins like dioxin affect newborn babies' habituation response. ${ }^{104}$ The study analyzed babies born to mothers who had regularly eaten fish from the Great Lakes. The study found that the babies had a diminished ability to adjust to irritants such as lights, rattles, and bells. ${ }^{105}$ In addition, the IJC in its Eighth Biennial Report stated that the U.S. Agency for Toxic Substances and Disease Registry is completing studies which have found behavioral abnormalities, such as the inability to "adapt to mild frustration," in children whose mothers consumed fish from the Great Lakes. ${ }^{106}$

\section{Controversy Surrounding the EPA's Draft Reassessment of Dioxin}

As with many other scientific studies, the EPA's Draft Reassessment of dioxin has been very controversial. While some in the chlorine and pulp

98. RE-EVALUATION OF DIOXIN, supra note 46, at 9.

99. Id. at 10. However, the research also shows a decrease in the incidence of breast cancer in Seveso. Scientists believe this may be due to the hormone mimicking abilities of dioxin. Id.

100. Putting the Lid, supra note 44, at 3. The veterans report higher rates of genitourinary and oropharyngeal cancers. Id. The U.S. Department of Veterans Affairs has also announced a relationship between exposure to Agent Orange in males and spina bifida in their children. George Claxton, Dioxin Threat, CHI. TRIB., July 9, 1996, $\S 1$, at 11 , available in Westlaw, 1996 WL 2687993.

101. See supra note 84.

102. Hormone Copycats: Effects on Humans, supra note 84, at 5.

103. Id.

104. Great Lakes: Study Finds Toxins Affect Newborn's Behavior, GREENWIRE, Sept. 27, 1995.

105. Id.

106. EIGHTH BIENNIAL REPORT, supra note 92, at 11. 
and paper industries have taken "pioneering steps"107 to address the perceived dioxin problems, others claim that the dioxin data is "based on half-truths, even fabrications." 108 The Science Advisory Board, chosen by the EPA to peer review its findings on dioxin, recently requested that the EPA provide better support for some of its conclusions on the risks of lowlevel exposure to dioxin to humans. ${ }^{109}$ The Draft Reassessment has also attracted the attention of Congress. Conservatives have promised to investigate "whether sound science is being distorted for preconceived policy ends, and the potential economic impact of future mandates based on this reassessment." 110 Current bills under review in Congress would also require the EPA to conduct risk assessment and cost-benefit studies before undertaking actions like dioxin regulation. ${ }^{111}$

Industry groups insist that the dangers of organochlorines, such as dioxin, have not been scientifically substantiated by the Draft Reassessment. They emphasize that "[a]lmost forty percent of U.S. jobs and income are in some way dependent" on chlorine. ${ }^{112}$ The elimination of chlorine would "deprive the public of a beneficial family of products and create significant negative economic effects." 113 Therefore, they contend that before substantial regulations are issued limiting or virtually eliminating the discharge of dioxin, the EPA's findings on low level exposure to dioxin should be scientifically substantiated. The industry groups also agree with Congress that a cost-benefit calculation should be used in evaluating dioxin.

However, the IJC has pointed out that cost-benefit evaluation is not the approach mandated by the GLWQA. The Agreement clearly states that "the discharge of any or all persistent toxic substances [should] be virtually eliminated." 114 Therefore, the IJC adopted a weight of the evidence approach. ${ }^{115}$ Has the EPA's Dioxin Reassessment and other studies demonstrated that the weight of the evidence shows the danger to human health from dioxin? The IJC believes that the answer to that question is yes

107. SEVEnTH BienNial REPORT, supra note 77, at 15.

108. Wigotsky, supra note 48 , at 16 .

109. Montague, supra note 43, at 2. See also Kathryn E. Kelly, Cleaning Up EPA's Dioxin Mess, WALL ST. J., June 29, 1995, available in Westlaw, 1995 WL-WSJ 8733972. For a summary of the Science Advisory Board's comments, see Kirk J. Finchem, Science Advisory Board Questions EPA's Dioxin Assessment Methods, Findings, PULP \& PAPER, Feb. 1, 1996, available in Westlaw, 1996 WL 8902068.

110. Montague, supra note 43, at 2.

111. See infra part III(C).

112. Wigotsky, supra note 48 , at 18.

113. Id.

114. 1978 GLWQA, supra note 28, at 1387.

115. See supra part $\Pi(C)(2)$. 
and demonstrates this by their continued efforts to eliminate dioxin and other organochlorines from the Great Lakes. ${ }^{116}$

\section{The UNITED STATES' EFFoRTS TO COMPLY}

\section{A. Legislative Acts and Administrative Regulations}

Since the 1972 GLWQA was signed, many legislative acts and regulations have been promulgated which influence the level of dioxin pollution in the Great Lakes. Due to the magnitude of acts and regulations that have had some impact, only the most effective will be considered here. For simplicity, only the acts and regulations affecting the dioxin emissions of pulp and paper mills will be examined. The acts to be discussed include the Great Lakes Water Quality Initiative, the Pollution Prevention Act of 1990, and the proposed Cluster Rule. As a background for the United States' efforts, the Clean Water Act and the Great Lakes Critical Programs Act will also be discussed. An analysis of the advantages and disadvantages of the United States' efforts will then be addressed and a discussion of the effects of legislation proposed by the 104th Congress will be considered.

\section{Clean Water Act}

In 1972, Congress enacted the Clean Water Act ("CWA") 117 over a veto by President Nixon. ${ }^{118}$ Water pollution had become such a problem in the United States that one senator remarked that "[o]ur planet is beset with a cancer which threatens our very existence." 119 The goals of the Act were "to restore and maintain the chemical, physical, and biological integrity of the Nation's waters." ${ }^{20}$ Over the past twenty years, the CWA has accomplished much in furtherance of this goal. In 1970, "only [thirty-six percent] of our rivers and lakes were safe for fishing and swimming."121

116. Environmentalists contend that the scientists who continue to say that the danger from dioxin is overstated are similar to the "tobacco scientists," who still claim that there is "no compelling evidence that tobacco causes lung cancer in humans." Montague, supra note 43 , at 2.

117. 33 U.S.C. $\$ 1251$ (1994) et seq.

118. Robert W. Adler Et Al., The Clean Water ACt 20 Years Later 1-2 (1993). President Nixon vetoed the Act on the grounds that it would result in "extreme and needless overspending." However, Congress took only one day to override the President's veto. Id.

119. Id. at 7 .

120. 33 U.S.C. § 1251(a) (1994).

121. The Clean Water Act: An American Success Story (online version), NATIONAL WILDLIFE FEDERATION, rev. June 13, 1995, at 1, available in Internet, http://www.igc. apc.org/nwf/pol/actionpg/issues/cwa1.html. 
However, approximately sixty-six percent of the rivers and lakes are safe for fishing and swimming today. ${ }^{122}$

Additional goals of the Act which affected the Great Lakes and dioxin were to eliminate the discharge of pollutants into navigable waters by 1985 and to prohibit the discharge of "toxic pollutants in toxic amounts." 123 However, the goal of zero discharge of pollutants has been an elusive target. While there has been considerable progress in reducing pollution from point sources, zero discharge of dioxin and other toxic pollutants has not yet been attained. ${ }^{124}$

\section{Great Lakes Critical Programs Act of 1990}

The Council of Great Lakes Governors signed the Great Lakes Toxic Substances Control Agreement in 1986. ${ }^{125}$ The purpose of this agreement was to "establish a framework for coordinated regional action in controlling toxic pollutants entering the Great Lakes system." 126 In 1989, the U.S. EPA began working with the Great Lakes states to develop a regional approach to water pollution control in the Great Lakes. ${ }^{127}$ Congress noted the work of the states and the EPA and codified their work by amending the CWA in 1990 with the Great Lakes Critical Programs Act ("Critical Programs Act"). ${ }^{128}$ The amendments required the EPA to issue a proposed and final Great Lakes Water Quality Initiative ("Initiative") and required the Initiative to contain numeric water quality criteria, implementation procedures, and antidegradation policies. ${ }^{129}$ The Critical Programs Act also required the states to adopt water pollution policies consistent with the Initiative within two years of publication of the final Initiative or face automatic promulgation of consistent state laws and regulations by the EPA. ${ }^{130}$ The Critical

122. Id.

123. 33 U.S.C. $\$ 1251$ (a) (1994).

124. ADLER, supra note 118 , at 17.

125. The Great Lakes Toxic Substances Control Agreement (online version), CouNCIL OF GrEAT LAKES GoverNORS, rev. Aug. 30, 1995, at 1, available in Internet, http://www.greatlakes.net:2200/partners/CGLG/gltsca.html.

126. Id. at 1 .

127. Allegra Cangelosi, A Major Skirmish in the Environmental Wars of the 104th Congress (online version), NORTHEAST-MIDWEST REVIEW, May 1995, at 1, available in Internet, http://gopher.great-lakes.net:2200/0/partners/NEMW/gli.txt.

128. Id. at 2.

129. John Knox, The EPA's Proposed Water Quality Guidance for the Great Lakes System: $A$ Uniform and Stringent Solution, 4 DiCK. J. ENVTL. L. \& PoL'Y 89, 92 (1994).

130. Id. 
Programs Act also "adds domestic legal teeth" to some provisions of the GLWQA by mandating RAP's and LaMP's. ${ }^{131}$

\section{Great Lakes Water Quality Initiative}

The Great Lakes Water Quality Initiative, also known as the Final Water Quality Guidance for the Great Lakes System, ${ }^{132}$ is the first significant step toward the United States meeting goals set out under the GLWQA. Although the Critical Programs Act required the EPA to release the final Initiative in 1992, it was not completed and signed by the EPA until March 13, 1995. ${ }^{133}$ As specified in the Critical Programs Act, the Great Lakes states now have until March 1997 to implement the provisions of the Initiative.

The goals of the Initiative are to establish minimum water quality standards in the Great Lakes in order to make the state laws more uniform and to make implementation of the GLWQA more uniform in the region. The major principles of the Initiative include:

(1) using the best available science to protect human health, aquatic life, and wildlife;

(2) recognizing the unique nature of the Great Lakes Basin Ecosystem;

(3) promoting consistency in standards and implementation procedures while allowing appropriate flexibility to states and tribes; ${ }^{134}$

(4) establishing equitable strategies to control pollution sources;

(5) promoting pollution prevention practices; and

131. SIXTH BIENNIAL REPORT, supra note 1, at 9. For a description of RAP's and LaMP's, see supra Part I(B)(3).

132. Final Water Quality Guidance for the Great Lakes System, 60 Fed. Reg. 15,366 (1995).

133. The EPA was required under the Clean Water Act amendments to release a draft Initiative by June 30, 1991 and final Initiative by 1992. However, near the end of 1992, a draft Initiative had not yet been released. Therefore, the National Wildlife Federation filed suit against the EPA on October 20,1992 seeking an order from the District Court to the EPA to publish the Initiative immediately. The EPA cited the "breadth and complexity of the issues" as reasons for the delay. Conservation Group Sues U.S. EPA over Delayed Great Lakes Water Standards, 15 Int'l Envtl. Rep. (BNA) No. 22, at 721 (Nov. 4, 1992).

134. For flexibility, the states or tribes may "choose to improve water quality by reducing air emissions or cleaning up contaminated sediments, rather than imposing additional requirements on wastewater dischargers." EPA, States to Restore Great Lakes (online version), EPA PRESS RELEASE, Mar. 13, 1995, at 1, available in Internet, gopher:// gopher.epa.gov/00/Press/PressReleases/1995/March/Day-13/pr-243. 
(6) providing accurate assessment of costs and benefits. ${ }^{135}$

A main focus of the Initiative is on twenty-two bioaccumulative pollutants. The Initiative names dioxin as a bioaccumulative chemical of concern ${ }^{136}$ and, therefore, sets strict limits on its discharge. For the first time, the EPA has set criteria to protect wildlife from long-term exposure to persistent toxic chemicals, such as dioxin. ${ }^{137}$ By targeting these persistent bioaccumulative chemicals, the EPA moves closer to reaching the GLWQA's requirement of "virtual elimination" of these chemicals. ${ }^{138}$

\section{Pollution Prevention Act of 1990}

Another law that has had a significant effect on the reduction of dioxin in the Great Lakes is the Pollution Prevention Act of 1990. ${ }^{139}$ Congress found that existing regulations were aimed at controlling pollution ${ }^{140}$ through "end of the pipe" regulation. In legislative findings, Congress stated that "significant opportunities for industry to reduce or prevent pollution at the source" exist, ${ }^{141}$ and that "[s]ource reduction is fundamentally different and more desirable than waste management and pollution control."142 Therefore, Congress declared that it was the national policy of the United States that pollution should be prevented or reduced at the source whenever feasible; pollution that cannot be prevented should be recycled in an environmentally safe manner whenever feasible; pollution that cannot be prevented or recycled should be treated in an environmentally safe manner whenever feasible; and disposal or other release into the environment should be employed only as a last resort and should be conducted in an environmentally safe manner. ${ }^{143}$

135. Final Water Quality Guidance for the Great Lakes System, 60 Fed. Reg. 15,366, 15,369-72 (1995):

136. Id. at 15,393 .

137. U.S. EPA to Publish Great Lakes Cleanup Plan, ECo-LOG WEEK, Apr. 7, 1995, at 2 available in Westlaw, 1995 WL 2406239.

138. The Final Great Lakes Water Quality Initiative Analysis of its Merits: What Good is the GLI? (online version), GREAT LAKES NATURAL RESOURCE CENTER, NÄTIONAL. WILDLIFE FEDERATION, June 1, 1995, at 3, available in Internet, http://www.great-lakes. net:2200/0/partners/NWF/gli/analysis/good.html. The EPA estimates that the Initiative will reduce the dumping of toxic pollution into the Great Lakes by 16 to 29 percent. Id. at 4 .

139. 42 U.S.C. \$13101-13109 (1994). For a summary of laws leading up to and resulting from the Pollution Prevention Act of 1990, see Robert F. Blomquist, Government's Role Regarding Industrial Pollution Prevention in the United States, 29 GA. L. REv. 349 (1995).

140. 42 U.S.C. § 13101(a) (1994) (emphasis added).

141. Id. (emphasis added).

142. Id.

143. 42 U.S.C.S. $\$ 13101(b)(1994)$. 
Source reduction is typically achieved through equipment or technology modifications, process or procedure modifications, reformulation or redesign of products, substitution of raw materials, and in-house improvements. ${ }^{144}$ The pulp and paper mills have developed new bleaching processes in order to reduce the sources of dioxin pollution. New bleaching techniques, using chlorine dioxide, oxygen delignification, hydrogen peroxide, and ozone, have been successful in substantially reducing or eliminating dioxin in the pulp and paper mills' effluent. ${ }^{145}$

\section{The Cluster Rule}

A cluster rule is a way to "efficiently and effectively incorporate all environmental-related activities of a particular industry within a common framework necessary for environmental protection."146 The proposed pulp and paper industry Cluster Rule ${ }^{147}$ is the EPA's first attempt to "integrate comprehensively air, water, and land pollution regulations" regarding dioxin. ${ }^{148}$ With this regulation, the EPA hopes to virtually eliminate the discharge of dioxin into water by pulp and paper mills and substantially reduce airborne discharges. ${ }^{149}$ Under this proposed rule, the EPA would establish minimum pollution control technology in pulp and paper mills and require mills to replace chlorine bleaching with chlorine dioxide bleaching, which would reduce dioxin discharges in wastewater by ninety-five percent. ${ }^{150}$ A small category of mills would be required to replace chlorine bleaching with totally chlorine-free bleaching processes which would eliminate dioxin discharges. ${ }^{151}$

144. John H. Sheridan, Pollution Prevention Picks Up Steam, INDUSTRY WK., Feb. 17, 1992, at 41, available in Westlaw, 1992 WL 3083339.

145. 1993-95 PRIORITIES, supra note 50, at 42-43.

146. 140 CONG. REC. S10,574-02, S10,596 (daily ed. Aug. 4, 1994) (statement of Sen. Bumpers).

147. Effluent Limitations Guidelines, Pretreatment Standards, and New Source Performance Standards: Pulp, Paper, and Paperboard Category, 58 Fed. Reg. 66,078 (1993).

148. Daniel J. Murphy, Regulating the Paper Industry: The Gov't's Demand for Paperwork Begets More, INVESTOR's BuS. DAILY, Sept. 27, 1994, available in Westlaw, 1994 WL 3233646.

149. Id.

150. Press Advisory: EPA Releases New Data on Pulp and Paper Discharges; Considers Regulatory and Voluntary Options, EPA, July 3, 1996, available in Westlaw, 1996 WL 367536.

151. 141 CONG. REC. H6104-01, H6106 (June 20, 1995) (statement of Rep. Solomon). 


\section{B. Advantages and Disadvantages of the United States' Efforts}

The United States' efforts to reduce dioxin in pulp and paper manufacturing in compliance with the GLWQA, such as the Great Lakes Water Quality Initiative and the Cluster Rule, have been controversial. While there have been advantages, such as a more than ninety percent reduction in dioxin discharges by pulp and paper mills since 1988, there have also been significant disadvantages. The regulations have been and continue to be very costly for the pulp and paper industry.

There are many advantages to the Great Lakes Water Quality Initiative. The issuance of the regulation is the beginning of real fulfillment of GLWQA goals by the United States. The Initiative also reduces toxic pollution and helps keep clean waters clean. It promotes a consistency in state laws that was severely lacking. Of course, it also helps to protect people and wildlife in the Great Lakes basin.

While the Initiative has many advantages, some serious disadvantages have also been pointed out. The Initiative is not entirely consistent with mandates of the GLWQA for three main reasons: (1) the Initiative is not a binational approach; (2) the regulation does not manage the Great Lakes as an ecosystem; and (3) no zero discharge or virtual elimination of persistent toxic chemicals is mandated by the Initiative. Also, some groups contend that the Initiative should be voluntary. The groups argue that when Congress referred to the Initiative as a "guidance" this implied that the Initiative was voluntary. However, others contend that the term "guidance" was used simply "to allow states appropriate flexibility in adapting their programs to the regional guidelines." 152

In response to the concerns over whether the Initiative is voluntary or a legitimate regulation, several groups filed suit against the EPA in July 1995. ${ }^{153}$ The Great Lakes Water Quality Coalition, a group made up of cities, agricultural groups, businesses, and trade associations, filed suit claiming that the Great Lakes Initiative is actually a regulation. ${ }^{154}$ They challenged the EPA's authority to promulgate the Initiative as a regulation and believed that the EPA has "overstepped its legal authority." 155

152. Cangelosi, supra note 127 , at 4.

153. Groups Seek Federal Appeals Court Review of Water Quality Guidance for Great Lakes, 26 Envtl. Rep. (BNA) No. 11, at 564 (July 14, 1995).

154. Id. See Great Lakes Water Quality Coalition v. EPA, No. 95-2639 (7th Cir. filed July 11, 1995).

155. Groups Seek Federal Appeals Court Review of Water Quality Guidance for Great Lakes, 26 Envtl. Rep. (BNA) No. 11, at 564 (July 14, 1995). Along with the Great Lakes Water Quality Coalition, the American Iron and Steel Institute filed suit challenging the Initiative. See id. (citing American Iron and Steel Institute v. Browner, No. 95-1348 (D.C. Cir. filed July 10, 1995)). 
Like the Initiative, the Cluster Rule has groups who support and disagree with the proposed rule. An advantage of the rule is that there is finally a goal of zero discharge of dioxin for some pulp and paper mills. Although this has been a goal of the GLWQA since 1978, the Cluster Rule is the first real step towards virtual elimination. However, some groups describe the Cluster Rule as "regulatory over-kill" 156 and "the biggest and most costly rule ever proposed by the EPA for a single industry." 157 One pulp and paper mill representative stated that the Cluster Rule had a "cost-tobenefit ratio of 10 to 1 at best, but more realistically closer to 100 to 1 ." 158 Industry statistics also show that the Rule would result in the closure of thirty-three mills, the loss of over 100,000 jobs, and a cost of $\$ 11.5$ billion over three years. ${ }^{159}$

However, the United States' efforts have been very effective overall. Dioxin discharges by pulp and paper mills have decreased by more than ninety percent since $1988 .{ }^{160}$ The pulp and paper industry now produces "less than one percent of the total dioxin generated in this country" according to industry sources. ${ }^{161}$ A problem with existing legislation is that it is a jumble of regulations from many different laws. 'The Cluster Rule is a good beginning at solving this problem. By combining regulations to govern a certain industry, ambiguity and confusion are removed. However, this also opens the door to intense lobbying by special interest groups of the industry. If the industry is powerful enough, it could prove difficult to promulgate and enforce the regulation.

\section{Effects of Proposed Congressional Legislation}

Several bills proposed in the 104th Session of the United States Congress could have a severe effect on enforcement of the GLWQA if passed. American and Canadian environmentalists are concerned that passage of the new bills would turn back the clock to a time when water was not safe to drink and rivers caught fire due to contamination. Canadian Environment Deputy Prime Minister Sheila Copps emphasized Canada's concern by stating that "some members of Congress appear to have become

156. Prepared Testimony of John A. Georges, Chairman and CEO International Paper Company, on Behalf of the Business Roundtable Before the Committee on Governmental Affairs of the United States Senate Re: Regulatory Reform and Irrational Regulations, FED. News Service WaSh. PACKAGE, Feb. 8, 1995, at 2, available in Westlaw, 1995 WL 6621448 [hereinafter Georges].

157. 141 CONG. REC. H6104-01, H6106 (daily ed. June 20, 1995) (statement of Rep. Solomon).

158. Georges, supra note 156 , at 2 .

159. Id. at 7.

160. Murphy, supra note 148 , at 3 .

161. Georges, supra note 156 , at 8 . 
radical anti-environmentalists."162 However, industrial groups praise the bills as reducing unnecessary and costly regulations on businesses.

One bill that has been proposed is H.R. 961, The Clean Water Amendments Act of 1995. The main provisions of the bill which affect the Great Lakes and dioxin are as follows: (1) makes the Great Lakes Water Quality Initiative a guidance only and voluntary for the states; ${ }^{163}(2)$ imposes extensive cost-benefit analyses and risk assessments for most Clean Water Act regulations; ${ }^{164}$ and (3) lets regulators consider any factors when setting standards for toxic discharges rather than the previous stringent, scientifically based standards. ${ }^{165}$ Many have called this bill the "Dirty Water Act." One Congressman stated that "H.R. 961 will actually reverse the progress we have made under current clean water law." 166

This bill was approved by the House on May 16, 1995. ${ }^{167}$ However, the bill stalled in the Senate committee when moderates prevented the bill from moving forward. ${ }^{168}$ Nevertheless, to "circumvent the Senate's delay, House members simply attached key Clean Water Act revisions as riders on the EPA appropriations bill." 169 In December 1995, the EPA appropriations bill passed the House and Senate with some of the riders still attached. ${ }^{170}$ President Clinton vetoed the bill which would have drastically cut the EPA's budget. ${ }^{171}$

This and many other proposed bills could have a serious effect on the Great Lakes and dioxin produced by pulp and paper mills. The trend in most of the bills seems to be a shift toward cost-benefit analysis, reduced regulation, and avoidance of taking private property without just compensation. Environmentalists claim that the risk assessment and costbenefit provisions would create an endless bureaucratic maze. EPA Administrator Browner concluded that more than $\$ 220$ million would be

162. Anne Swardson, Canada Protests U.S. Regulatory Bill, WASH. POST, July 25, 1995 , at A10, available in Westlaw, 1995 WL 9253758.

163. 141 CONG. REC. H5053-09 (May 16, 1995) (statement by Rep. Kaptur).

164. H.R. 961 Threatens Public Health and Repeals Essential Protections (online version), NATIONAL WILDLIFE FEDERATION, June 15, 1995, at 1, available in Internet, http://www.igc.apc.org/nwf/pol/actionpg/issues/cwa961.html. See also H.R. REP. No. 961, 104 th Cong., 1st Sess., $\$ 323$ (1995).

165. Clean Water Background Facts - Why HR 961 Must Be Stopped, SIERRA CLUB LEGAL DEFENSE FUND, Apr. 27, 1995, at 3.

166. 141 CONG. REC. H5053-09, H5054 (May 16, 1995) (statement of Rep. Kaptur).

167. Vicki Monks, Capitol Games: Environmental Policies of the 104th Congress, NATional. WildLifE, Apr. 14, 1996, available in Westlaw, 1996 WL 9822884.

168. Id.

169. Id.

170. Id.

171. Id. 
required to make the risk assessments. ${ }^{172}$ Additionally, opinion polls show that "a substantial majority of voters - both Republican and Democrat oppose rolling back environmental protections." 173 In fact, a Times-Mirror poll showed that seventy percent of Americans believe that "pollution laws have not gone far enough."174

\section{CANADA'S EFFORTS TO COMPLY}

\section{A. Legislative Acts and Administrative Regulations}

Like the United States, Canada and its provinces have issued many laws and regulations in response to the GLWQA. As with the United States' efforts, this note will discuss the major legislation and regulations affecting the dioxin discharges of pulp and paper mills. These include the CanadaOntario Agreement Respecting the Great Lakes Ecosystem and the Federal Toxic Substances Management Policy. As a background for these laws and regulations, the Canada Environmental Protection Act and Great Lakes 2000 will also be discussed.

\section{Canada Environmental Protection Act}

The Canada Environmental Protection Act ("CEPA") was enacted in $1987^{175}$ and took effect on June 30,1988. ${ }^{176}$ This Act is the Canadian federal government's main environmental statute. ${ }^{17}$ The Act superseded the existing Clean Air Act, Environmental Contaminants Act, and Ocean Dumping Act. ${ }^{178}$ CEPA was enacted shortly after a "toxic blob" of contaminants from a Dow Chemical plant leaked into the St. Clair River and threatened drinking water in Windsor and Detroit. ${ }^{179}$ Existing environmental legislation did not allow the Environment Minister to do anything about the "blob."180 This incident and the realization that "existing legislation was not adequate for

172. Breach of Faith: How the Contract's Fine Print Undermines America's Environmental Success (online version), NATURAL RESOURCES DEFENSE COUNCIL, Feb. 1995, at 3, available in Internet, http://www.cs.cmu.edu/ jab/pol/breach.html. Administrator Browner was referring specifically to the proposed bill H.R. 9.

173. Monks, supra note 167.

174. Id.

175. G. Bruce Doern \& Thomas Conway, The Greening of Canada: Federal INSTITUTIONS AND DECISIONS 14 (1994).

176. Roger Cotton \& John Zimmer, Canadian Environmental Law: An Overview, 18 CAN.-U.S. L.J. 63, 65 (1992).

177. DOERN \& CONWAY, supra note 175 , at 14.

178. Id. at 21 .

179. Id. at 221-22.

180: Id. at 222 . 
addressing the 'new' toxic contaminants" triggered pressure to enact new environmental legislation and resulted in CEPA. ${ }^{181}$

With respect to dioxin and other toxic substances, CEPA contains provisions for information gathering, controls on substances new to Canada, broad regulatory authority, interim orders for emergencies, clean-up of unauthorized releases, authority to direct remedial measures, and export and import controls. ${ }^{182}$ CEPA, along with the Fisheries Act which protects fish habitats, have been used to tighten controls on pulp and paper mill discharges. ${ }^{183}$ The Pulp and Paper Mill Effluent Chlorinated Dioxins and Furans Regulations, promulgated under CEPA in 1991, established stringent limits on pulp and paper mill discharges of dioxins. ${ }^{184}$ However, the original 1994 deadline was extended to December 31, 1995 for many of the pulp and paper mills. ${ }^{185}$

\section{Great Lakes 2000}

The Great Lakes 2000 program, announced in April, 1994, is intended to help Canada meet its obligations under the GLWQA. ${ }^{186}$ The main objectives of the program are: (1) restoration of degraded sites; (2) prevention and control of pollution; and (3) conservation and protection of human and ecosystem health. ${ }^{187}$ The seven-year program renews Canadian efforts to restore, protect, and sustain the Great Lakes until the year 2001. ${ }^{188}$ One goal of the program is the virtual elimination of persistent, bioaccumulative, and toxic substances, such as dioxin. ${ }^{189}$ Canada has invested over $\$ 37$ million in nearly 200 cleanup projects in Canada's seventeen Great Lakes Areas of Concern and other priority areas. ${ }^{190}$

181. Id. at 228. Other incidents which occurred at about the same time as the "toxic blob" and spurred concern about existing environmental legislation include the Love Canal in New York in 1978, the derailment of twenty-one railway cars carrying toxic chemicals in Ontario in late 1979, and reports of deaths of gulls and ducks in Toronto in 1979. Id. at 220.

182. Id. at 224.

183. Summary of Environmental Law in Canada, §9.2 Point Sources (online version), at 1 , available in Internet, http://www.cec.org/english/database/law/canada/09/09-02.html.

184. Id. See also Roger Cotton \& Cara Clairman, The Effect of Environmental Regulation on Technological Innovation in Canada, 21 CAN.-U.S. L.J. 239, 247 (1995).

185. Extensions Expire: Mills Can Expect Intensive Scrutiny, ECO-LOG WEEK, Jan. 19, 1996, at 2, available in Westlaw, 1996 WL. 8729199.

186. Great Lakes 2000 (online version), ENVIRONMENT CANADA, July 4, 1995, at 2 , available in Internet, http://www.cciw.ca/glimr/metadata/gl2000/intro.html.

187. Id. at 1 .

188. Id.

189. Id.

190. Great Lakes 2000 Cleanup Fund Program Highlights - 1995 (online version), ENVIRONMENT CANADA, Sept. 27, 1995, at 1, available in Internet, http://www.cciw.ca/ glimr/data/cleanup-fund-95/intro.html. The major success story of the Great Lakes 2000 


\section{Canada-Ontario Agreement Respecting the Great Lakes Ecosystem}

On July 6, 1994, the governments of Canada and Ontario signed the Canada-Ontario Agreement Respecting the Great Lakes Ecosystem ("COA"). The COA "synchronize[s] the activities of the federal . . . and provincial governments and work[s] towards the achievement of the three objectives" of the Great Lakes 2000 plan. ${ }^{191}$ The objectives of the plan include restoring degraded areas, preventing and controlling pollution, and conserving and protecting human and ecosystem health. ${ }^{192}$ The purpose of the COA is "to renew and strengthen planning, cooperation and coordination between Canada and Ontario in implementing actions to restore and protect the ecosystem, to prevent and control pollution into the ecosystem, and to conserve species, populations and habitats in the Great Lakes Basin Ecosystem." 193 The COA is meant to substantially meet Canada's obligations under the GLWQA. ${ }^{194}$

Dioxin pollution is affected by the second objective of preventing and controlling pollution. The COA states that " $[t]$ he ultimate goal . . . is to achieve the virtual elimination of persistent, bioaccumulative and toxic substances from the Great Lakes Basin Ecosystem by encouraging and implementing strategies consistent with the philosophy of zero discharge." 195 The agreement lists dioxin as one of thirteen Tier I pollutants. ${ }^{196}$ Tier I pollutants "require immediate action to eliminate their use, generation, or release in the Great Lakes environment." 197 A ninety percent reduction in the use, generation, and release of dioxin by the year 2000 is sought. ${ }^{198}$

The COA has achieved the following accomplishments relating to dioxin and the pulp and paper industry:

program has been the cleanup of Collingwood Harbour. The cleanup included "improved sewage treatment operations; new removal methods for contaminated harbour sediments; and innovative bio-engineering to rehabilitate fish and wildlife habitats and control erosion." Id. at 5 .

191. Great Lakes 2000, supra note 186, at 2.

192. Government of Canada, ENVIRONMENT Canada, Canada-Ontario AGREEMENT RESPECTING THE GREAT LAKES BASIN ECOSYSTEM 2 (1994).

193. Id. at 1.

194. Id.

195. Id. at 4.

196. Id. at 11 .

197. Id. at 4. Tier II pollutants, which include anthracene, cadmium, dichlorobenzene, and others, are subject to voluntary reductions only. Id. at 5-6.

198. Id. at 5. Five other Tier I pollutants, aldrin/dieldrin, chlordane, DDT, mirex, and toxaphene, which are all pesticides, are all subject to zero discharge by 1996 rather than the $90 \%$ reduction by the year 2000 . Id. at $4-5$. 
(1) a ninety percent drop in dioxin found in herring gull eggs since the 1970s;

(2) conventional pollution discharges in pulp and paper mills cut by seventy-five percent since 1972 ;

(3) chlorinated organic compounds from bleached kraft mills down more than fifty percent since 1989; and

(4) establishment of goals of zero discharge of organochlorines from Kraft mills by 2002 in Ontario. ${ }^{199}$

\section{Federal Toxic Substances Management Policy}

The Federal Toxic Substances Management Policy was released by the Canadian government in June $1995 .{ }^{200}$ The main objectives of the policy are the virtual elimination of persistent, bioaccumulative, toxic substances produced by human activity and the "management of other toxic substances and substances of concern, throughout their entire life cycles, to prevent or minimize their releases into the environment."201 The policy stresses preventive and precautionary management for toxic substances. ${ }^{202}$

As part of the Toxic Substances Management Policy, chlorinated substances are managed under a five-part action plan, which includes:

(1) targeting action which focuses on critical uses and products;

(2) improving the scientific understanding of chlorine and its impacts on the environment and human health;

(3) detailing socio-economic and public health studies on the use of chlorinated substances and their alternatives;

(4) improving access to information for Canadians; and

199. Canada-Ontario Great Lakes Partnerships, CANADA-ONTARIo AgreEment RESPECTING THE GREAT LAKES BASIN ECOSYSTEM 1994 BACKgROUNDER PROGRESS ON THE GREAT LAKES 1 (July 6, 1994). For more information regarding the COA, see First Progress Report Under the 1994 Canada-Ontario Agreement, PARTNERSHIPS FOR THE GREAT LAKES, Sept. 18, 1995, available in Internet, http://www.cciw.ca/glimr/data/coa-first-report/coa.html.

200. Government of Canada, Environment Canada, Toxic Substances MANAGEMENT POLICY (June 1995), available in the Internet, http://www.doe.ca/toxics/ toxic1_e.html. For more information on the Toxic Substance Management Policy, see also Government of Canada, Environment Canada, Toxic Substances Management POLICY REPORT ON PUBLIC CONSUlTATIONS (June 1995) and GOVERNMENT OF CANADA, Environment Canada, Toxic Substances Management Policy Persistence and BIOACCUMULATION CRITERIa (June 1995).

201. TOXIC SubSTANCES MANAGEMENT POLICY, supra note 200, at 1-2.

202. Federal Toxics Policy Places Onus on Industry (online version), ENVIRONMENT CANADA, June 2, 1995, at 1, available in Internet, http://www.doe.ca/toxics/toxpre_e.html. 
(5) promoting international efforts for global action on chlorinated substances. ${ }^{203}$

The principal uses of chlorine or chlorine containing compounds are polyvinyl chloride ("PVC"), pulp and paper processes, and solvents. ${ }^{204}$ Industries which produce chlorinated substances that are persistent and toxic, such as the pulp and paper industry, will be affected the most by this policy. Although the pulp and paper industry has already decreased chlorine use by forty-five percent since $1988,{ }^{205}$ this policy sets a goal of totally chlorine free bleaching processes by pulp and paper mills.

\section{B. Advantages and Disadvantages of Canada's Efforts}

In analyzing the advantages and disadvantages of Canada's efforts to comply with the GLWQA, it is helpful to discuss the fundamental differences between the political and economic systems of the United States and Canada. In Canada, "[g]overnmental authority is divided between a national government . . . and twelve regional governments. ${ }^{206}$ The Canadian Constitution does not assign exclusive responsibility for the environment to either the federal or provincial governments. ${ }^{207}$ Historically, the provinces have regulated environmental problems. ${ }^{208}$ However, over the last decade, the federal government has increased its role in protecting the environment. ${ }^{209}$

Several features of Canada's political system are substantially different from those in the United States. One difference is the concept of separation of powers. While in the United States separation of power is a fundamental concept between the legislative, executive, and judicial branches, in Canada, there exists no separation of powers between the legislative and executive branches. ${ }^{210}$ This "lack of effective constraint" on the executive branch's rule-making powers leads to "autocratic decision-making." 11

203. Environment Minister Outlines Approach to Deal with Chlorinated Substances, Canada NewsWire, Oct. 25, 1994, at 1, available in Westlaw, CANWIRE 14:27:00 [hereinafter Environment Minister Outlines].

204. Id. at 2.

205. Id. at 3.

206. Cotton \& Zimmer, supra note 176 , at 63.

207. Id.

208. Id. at 65 .

209. Id.

210. John L. Howard, Industrial Policy and Environmental Regulation - Canada, 19 CAN.-U.S. L.J. 315, 319 (1993).

211. Id. 
A second fundamental difference is that there is no judicial review of the regulation-making process in Canada. ${ }^{212}$ Since the Canadian legislature typically enacts only broad statutory standards, both the agency and the executive have wide discretion to define the broad standards. The agency's definitions of these standards are not subject to review by the courts. ${ }^{213}$ In contrast, judicial review of agency decisions is allowed in the United States. Although judicial review prevents unelected bureaucrats from imposing regulations not within the scope of the statute, some have described the United States' system as "extraordinarily crude, costly, litigious and counterproductive." 214 Such commentators contend that the system "empower[s] the courts and counsel for the litigants in contested cases to dominate or even capture the public policy agenda." 215

A third fundamental difference in the political systems involves the takings issue. In the United States, the Fifth Amendment prohibits the taking of private property for public use "without just compensation." This has been a significant issue in bills proposed before the 104th United States Congress. ${ }^{216}$ However, in Canada, "a corporation is not entitled to claim any constitutional protection of its property rights, even where the effect of a statute is outright expropriation of its property."217

A last fundamental difference between the United States and Canada involves the extent to which pulp and paper mills affect the economy. In Canada, the forest industry is one of the largest industries and employs 239,000 workers. ${ }^{218}$ The importance of this industry obviously makes it more difficult to promulgate and enforce strict regulations on pulp and paper mills due to lobbying strengths.

As for the effectiveness of the statutes and regulations discussed above, it is important to remember that the area of environmental law is still in its "infancy" in Canada. ${ }^{219}$ Canadian legislators have been able to analyze the effectiveness and workability of U.S. legislation, which was implemented over a decade before CEPA. As a result, they have promulgated equally tough standards without the "endless U.S.-style litigation."220

The COA and the Toxic Substances Management Policy are steps in the right direction toward effectively regulating dioxin pollution. However,

212. Id.

213. Id. at 324 .

214. Id. at 325 (quoting Bruce A. Ackerman \& Richard B. Stewart, Reforming Environmental Law, 37 STAN. L. REV. 1333 (1985)).

215. Id.

216. See supra part III(C).

217. Howard, supra note 210 , at 326.

218. Cotton \& Clairman, supra note 184 , at 246.

219. Roger Cotton \& John S. Zimmer, The Canadian Environmental Legal Regime: A Road Map for the Foreign Investor, 28 SAN DIEGO L. REV. 745 (1991).

220. DOERN \& CONWAY, supra note 175, at 131. 
environmental groups claim that the COA fails to implement zero discharge for dioxin as recommended by IJC. ${ }^{221}$ They claim that the Agreement is "a smoke and mirrors exercise designed to give the impression that governments have undertaken new initiatives to clean up the Great Lakes."222 The groups also charge that the COA "targets a mere handful of toxins [for phasing out], many of which have already been withdrawn or banned."223

Since the Toxic Substances Management Policy was just recently initiated, it is too early to analyze its success on the virtual elimination of toxic, persistent organochlorines. In addition to the federal government's efforts, Ontario has also enacted regulations intended to achieve zero discharge of organochlorines and other chemicals in the pulp and paper industry. ${ }^{224}$ Although virtual elimination of dioxin has not yet been achieved, through the laws discussed above, other federal and provincial pulp and paper regulations, and voluntary measures, dioxin discharges by Canadian mills have been reduced by ninety-eight percent. ${ }^{225}$ However, this success has recently been threatened by government plans to revoke the regulation in the COA that would require pulp and paper mills to virtually eliminate dioxin by the year 2002. ${ }^{226}$ The newly elected Ontario government has begun to "stead[ily chip] away at laws that protect the environment in the name of job creation." 227

\section{RECOMMENDATIONS AND CONCLUSIONS}

Most people would agree that a ninety-eight percent reduction in the production of a pollutant by an industry would be a sufficient decrease. This is especially true if a substantial amount of capital would have to be expended to achieve a $100 \%$ reduction in the discharge. However, this philosophy cannot be applied to the discharge of dioxin. Since dioxin is bioaccumulative and persistent, the release of even minute amounts will accumulate and cause harm to humans and animals. In fact, even though discharge levels of dioxin into the Great Lakes have been substantially reduced in the last two decades, concentration levels in Great Lakes fish

221. Canadian Environment Groups Pan Pact to Clean Up Great Lakes Basin Ecosystem, Int'l Env't Rep. Current Rep. (BNA), No. 15, at 647 (July 27, 1994).

222. Id.

223. Id.

224. SEVENTH BiENNIAL REPORT, supra note 77, at 12.

225. Env. Minister Outlines, supra note 203.

226. Brian McAndrew, Ontario Out to Sink Pollution Law, THE TORONTo STAR, July 26, 1996, at A5, available in Westlaw, 1996 WL 3378383.

227. Environmental Damage: The Harris Government Mistakenly Believes That Job Creation Means Less Protection for the Environment, THE OTTAWA CITIZEN, July 10, 1996, at A14, available in Westlaw, 1996 WL 3609705. 
have not shown signs of decline. ${ }^{228}$ Scientists believe this is due to dioxin accumulating in the Lake sediments where the dioxin is consumed by fish. ${ }^{229}$ Even if extremely small amounts of dioxin are released, it will continue to accumulate in the Lake soils and contaminate fish.

Some groups advocate the use of risk assessments and contend that there is not enough evidence at this time of the health effects of low levels of dioxin to warrant costly regulation. Although risk assessments are useful tools, the IJC has specifically rejected their use in determining which chemicals can be discharged into the Great Lakes. ${ }^{230}$ Risk assessments, as advocated by industry representatives, are not "necessary or justified if the primary goal is to protect public health or prevent pollution." ${ }^{231}$ When a risk assessment is performed, the purpose is to define an acceptable level of exposure. However, this "contravenes the goal of eliminating exposures to toxic materials" as required by the Great Lakes Water Quality Agreement, and this also "assumes a degree of precision that risk assessment does not possess." 232

The scientific uncertainty of the effects of dioxin at low level exposures is outweighed by the damage that could occur while years are spent trying to prove a "conclusive link" ${ }^{233}$ between dioxin and harm to human and animal health. The weight of the evidence approach should be recognized and supported by both countries and other interested parties in order to prevent further harm from occurring. As Adele Hurley, former Canadian co-chair of the IJC, pointed out, the weight of the evidence approach is used every day in courts to settle disputes. ${ }^{234}$ Hurley believes it is "an indefensible double standard" that the weight of the evidence approach is used for "settling arguments between companies but not to protect human health."235

Both the United States and Canada should strive for virtual elimination and zero discharge of dioxin. In order to accomplish this, the existing legislation and regulations in both countries should be extended to set a goal of mandatory zero discharge in the pulp and paper industry and other industries which produce dioxin. The United States' Cluster Rule is a good beginning to reach this goal. However, since the shift to totally chlorine free

228. Lake Ontario's Dioxin Level Still High and Bottom-feeder the Likely Culprit, THE TORONTO STAR, July 13, 1996, at C6, available in Westlaw, 1996 WL 3375902.

229. Id.

230. Robert R. Kuehn, The Environmental Justice Implications of Quantitative Risk Assessment, 1996 U. ILL. L. REV. 103, 169 (1996).

231. Id. at 168.

232. Id. at 170 .

233. SEVENTH BIENNIAL REPORT, supra note 77, at 27.

234. Cameron Smith, Great Lakes Co-chair Has Faith in Us, THE TORONTO STAR, June 29, 1996, at E6, available in Westlaw, 1996 WL 3373583.

235. Id. 
bleaching is mandated for only certain mills, this rule needs to be modified to include all pulp and paper mills in the shift away from chlorine bleaching. The proposed Congressional bills amending the Clean Water Act and reducing the EPA's budget should also be rejected due to the tremendous environmental harm they could cause throughout the United States and especially in the Great Lakes. Canada's COA is also a good start in achieving the elimination of dioxin. However, the COA does not mandate zero discharge for dioxin. This situation could be remedied by proper implementation of the Toxic Substances Management Policy's chlorinated substances plan. In addition, the IJC recently expressed concern with "proposals to weaken regulatory frameworks that underpin pollution control and other effective programs, including reporting and compliance requirements" and the "erosion of funding and expertise for research, monitoring and enforcement, and transferred responsibilities to other levels of government without the requisite resources."236

In addition to legislative and regulatory changes that would strengthen the goal of zero discharge of dioxin, the support of the pulp and paper industry is also necessary. Many industry representatives have stated that the cost of achieving zero discharge outweighs the benefits to human and wildlife health. However, studies have shown that source reduction efforts in certain mills have made them more efficient and profitable. Mills which invested earlier in totally chlorine free processes have a higher income growth than mills which did not invest in the new processes. ${ }^{237}$ In addition, another study showed that "there is no significant difference between the average cost of modifications needed to make paper without dioxin and the cost of switching to other new technologies that reduce, but don't eliminate dioxin emissions." 238

These studies show that those in the pulp and paper industry resisting the change to totally chlorine free technology should replace "the old mindset of 'jobs vs. environment" "with a new mindset of "environment = jobs." 239 As Canada's Deputy Prime Minister and Minister of the Environment, Sheila Copps, stated, "Avoiding environmental solutions is costing the economy; addressing environmental solutions is an economic opportunity." 240 This view was also emphasized by the IJC in their Seventh Biennial Report on the Great Lakes. The IJC stated that "[i]t is important

236. EIGHTH BIENNIAL REPORT, supra note 92 , at 6.

237. Chad Nehrt, Process Changes Pay Off for Mills Investing in Pollution Control, PULP \& PAPER, Sept. 1995.

238. Ken Ward Jr., Dioxin Costs Examined, Charleston Sunday GaZETTE-MaIl, June 30, 1996, at 1B, available in Westlaw, 1996 WL 5196895.

239. SEVENTH BIENNIAL REPORT, supra note 77, at 20.

240. Great Lakes 2000 Cleanup Fund Program Highlights - 1995 (online version), supra note 190 , at 3 . 
and inevitable that the business sector act increasingly to lead rather than resist a broad movement towards manufacturing processes that eliminate the production and use of persistent toxic substances." 241 The support of industry and business sectors is necessary to be successful in eliminating the discharge of dioxin and other persistent toxic chemicals from our waters.

Along with government and industry support, public support is necessary to achieve success in environmental cleanup. Although dioxin has received more public attention in recent years, most people still do not realize the dangers and health effects of dioxin and similar chemicals. Additionally, most people have never heard of the Great Lakes Water Quality Agreement. Publicity is necessary to inform the public and pressure the governments and industry into making changes to protect the health of citizens. "In the end, it will be ordinary people who will change public policy regarding the array of environmental pollutants affecting their lives and the world. No one else can effectively counter the opposition of powerful interests with vested economic stakes in our current uses of [persistent, bioaccumulative] toxic chemicals."242

Only by cooperation between the governments of the United States and Canada, industries, and the public can the discharge of toxic pollutants, such as dioxin, into the Great Lakes be eliminated as the governments agreed to do when they signed the Great Lakes Water Quality Agreement. Although substantial steps have been made toward cleaning up the Great Lakes, there is still more work to be done. A recent report by the United States and Canada found that the loadings of persistent toxic contaminants, levels of chemical contaminants in fish and herring gulls, and concentrations in water were "mixed/improving" from the peak levels that were found. ${ }^{243}$ More efforts are needed to reach a rating of "good/restored" for the level of toxic contaminants in the Great Lakes. The combined efforts of the governments of Canada and the United States, industries, and the citizens of both countries are necessary to completely restore the Great Lakes into a safe, healthy legacy for our children.

Christina D. Arvin*

241. SEVENTH BIENNIAL REPORT, supra note 77, at 15.

242. Hormone Copycats: Solutions (online version), GREAT LAKES NATURAL RESOURCE Center, NATIONAl Wildlife Federation, Apr. 4, 1994, at 5, available in Internet, http://www.great-lakes.net:2200/0/partners/NWF/toxics/hcc5-sol.html.

243. State of the Great Lakes 1995: Executive Summary (online version), ENVIRONMENT CANADA, Aug. 25, 1995, at 4, available in Internet, http://www.cciw.ca/glimr/data/soglfinal-report/intro.html.

* J.D. candidate, 1997, Indiana University School of Law - Indianapolis; B.S.C.E., 1993, Purdue University. 